\title{
WATER EROSION UNDER THREE TILLAGE METHODS IN A CULTIVATION OF Eucalyptus benthamii ${ }^{1}$
}

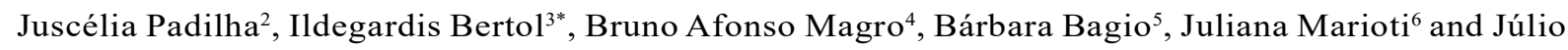 \\ César Ramos ${ }^{7}$
}

\footnotetext{
${ }^{1}$ Received on 28.08.2017 accepted for publication on 14.11.2017.

${ }^{2}$ Instituto Federal Catarinense, Blumenau, Santa Catarina - Brasil. E-mail: <junaflorestal@hotmail.com>.

${ }^{3}$ Universidade do Estado de Santa Catarina, Departamento de Solos, Lages, SC - Brasil. E-mail: <ildegardis.bertol@udesc.br>. ${ }^{4}$ Universidade Federal do Paraná, Mestrado em Engenharia Florestal, Curitiba, Paraná-Brasil. E-mail:<bruno.magro@yahoo.com.br>.

${ }^{5}$ Universidade do Estado de Santa Catarina, Programa de Pós-Graduação em Ciência do Solo, Lage, SC - Brasil. E-mail: <barbarabagio@yahoo.com.br>.

${ }^{6}$ Associação Sulina de Crédito e Assistência Rural, São José dos Ausentes, RS - Brasil. E-mail: <julianamarioti@gmail.com>. ${ }^{7}$ Empresa de Pesquisa Agropecuária e Extensão Rural de Santa Catarina, Chapecó, SC-Brasil. E-mail: <julioramos@epagri.sc.gov.br>. *Corresponding author.
}

ABSTRACT - Soil tillage influences the development of forests planted in the initial phase, which affects some hydrological processes and water erosion. The objective of this study was to quantify the water losses (WL) and soil losses (SL) by water erosion, between the second and third years of eucalyptus (Eucalyptus benthamii) crop, in an experiment located in southern Brazil, on a Humic Dystrudept. Was study three soil tillage treatments: i) subsoiling in downslope direction (SD); ii) subsoiling in contour on the slope (SC); iii) manual holes (MH). The plots had a dimension of $12 \times 24 \mathrm{~m}$, being the slope-wise length the greatest, monitored by tanks placed at the lower end for runoff collection. Runoff volume measurement and sampling for subsequent calculation of WL and SL was carried out weekly, corresponding to the rains accumulated during the week. The crop of eucalyptus in SD treatment, weakened the soil as to the water erosion in relation to the crop made in SC and in $\mathrm{MH}$; the difference was $25 \%$ for the WL and $53 \%$ for the SL. Eucalyptus reforestation played an important role in the control of water erosion, regardless of the type of soil tillage. The SL due to water erosion were more influenced than the WL, regardless of the type of soil crop used. WL and SL are related to each other and to rainfall height in positive linear relationship, regardless of the type of soil preparation used for eucalyptus planting.

Keywords: Reforestation; Water loss; Soil conservation.

\section{EROSÃO HÍDRICA EM TRÊS MÉTODOS DE PREPARO DO SOLO NUM CULTIVO DE EUCALYPTUS BENTHAMII}

RESUMO - O preparo mecânico do solo é uma das operações mais importantes de manejo na fase inicial de desenvolvimento das florestas plantadas, pois afeta alguns processos do ciclo hidrológico e a erosão hidrica, sendo, por isso, importante o conhecimento dessas variáveis. Com o presente trabalho objetivouse quantificar as perdas de água e solo por erosão hídrica pluvial, entre o segundo e o terceiro ano de cultivo do Eucalyptus benthamii, em um experimento situado no Sul do Brasil, sobre um Cambissolo Húmico alumínico léptico, em três tratamentos de preparo do solo: i) preparo com subsolagem a favor do declive; ii) preparo com subsolagem em contorno ao declive; iii) preparo em covas com coveador manual. As parcelas tinham dimensão de $12 \times 24 \mathrm{~m}$, com o maior comprimento no sentido do declive, monitoradas por tanques colocados ao seu final para coleta da enxurrada. A medição do volume e a coleta de amostras da enxurrada para posterior cálculo de perdas de água e solo foi realizada semanalmente, correspondendo às chuvas acumuladas na semana. O preparo do solo a favor do declive apresentou perdas de água e solo maiores do que em contorno e em covas, cuja diferença foi $25 \%$ para as perdas de água e $53 \%$ para as perdas de solo. O crescimento das plantas ocasionou sensivel diminuição do escoamento superficial, evidenciando que o reflorestamento, nas condições experimentais, pode controlar a erosão hídrica. As perdas de solo por erosão hídrica foram influenciadas em magnitude maior do que as perdas de água, independentemente do sistema de preparo do solo e da forma de plantio de Eucaliptus benthamii.

Palavras-Chave: reflorestamento; perdas de água; conservação do solo. 


\section{INTRODUCTION}

Soil rainfall erosion occurs in three phases, disintegration, transport and deposition, and it is cause by the impact of the droplets and by the surface runoff, influenced by climate, soil, topography, soil cover and management and complementary conservation practices (Wischmeier and Smith, 1978). Soil cover and management are the most important factors in erosion control, and when they are due to vegetal residues they are more efficient than by the plants since the residues intercept raindrops and dissipate their kinetic energy at ground level (Hudson, 1995).

The cover by residues increases the infiltration of water in the soil and reduces the surface runoff, reducing sediment transport (Chirino et al., 2006; Panachuki et al., 2011). The cover by plants dissipates the energy of the rain through the canopy and induces the arrival of water on the soil in the zone of the roots, through the trunk (Oliveira et al, 2013). The roots increase the stability of the soil, open channels and, with this, the water infiltrates with ease.

The preparation of the soil in the phase of implantation of the forest makes possible the development of the plants in their initial phase; more intense preparations lead to greater erosion in this phase (Pires et al. 2006; Magro, 2012). The mechanical tillage alters the physical characteristics, compacting the soil and increasing water erosion (Amaral et al., 2008; Pires et al., 2006; Magro, 2012), unlike the non-mechanized preparation (Pires et al., 2006; Oliveira, 2012). The operations of the soil tillage associated with the previous removal of vegetal residues from the soil surface increase soil degradation and water erosion (Bertol et al., 2010).

The type of soil preparation and the way of planting forests vary in Brazil, predominating the planting with preparation in a sloping direction. Soil cultivation with tillage on-contour, alone, can reduce soil losses by up to $50 \%$ and water losses by up to $40 \%$ relative to the cultivation down the slope (Wischmeier and Smith, 1978; Luciano et al., 2009). The minimum cultivation, being a soil conservationist practice, has been used in forest areas in recent years (Gonçalves and Stape, 2002; Martins et al., 2003; Brito et al., 2005; Pires et al., 2006; Oliveira et al., 2013). However, in the bias of the advantages of this tillage system, planting is routinely done in lines within subsoil grooves opened by subsoiler, parallel to the slope or, at best, transversely to the slope out of contour, which has contributed to increasing water erosion in these areas.

The most used types of equipment in the preparation of the ground for the minimum cultivation of forests are the subsoiler, the scarifier, and the digger (Wichert, 2005; Baptista and Levien, 2010). These types of equipment present variable effects in the soil; they affect water erosion due to the way they are used (Gonçalves and Stape, 2002). In Brazil, little information exists on the effects of soil preparation carried out with these types of equipment on water erosion in quantitative terms (Pires et al., 2006; Magro 2012), which justifies the present research.

The objective of this study was to quantify water and soil losses due to water erosion in the period from the second to the third year after the soil preparation and planting of a forest of eucalyptus.

\section{MATERIALAND METHODS}

The experimental area is located in the mountainous region of Santa Catarina (W50 05 'and $\mathrm{S} 27^{\circ} 33^{\prime}$ '), at an altitude of $841 \mathrm{~m}$. The climate of the region is of the type $\mathrm{Cfb}$, according to Köppen, with the annual precipitation of 1,533 $\mathrm{mm}$ (SCHICK et al., 2014). The soil is a Humic Dystrudept (Soil Survey Staff, 2014), with $340,184,234$ and $237 \mathrm{~g} \mathrm{~kg}^{-1}$ of clay, coarse sand, fine sand, and silt respectively 3.2 and $31 \mathrm{mg} \mathrm{dm}^{-3}$ of phosphorus $(\mathrm{P})$ and potassium $(\mathrm{K})$, respectively, $4.7 \%$ of organic matter $(\mathrm{OM})$ and 1.1 and $0.8 \mathrm{cmol}_{\mathrm{c}} \mathrm{dm}^{-3}$ of calcium $(\mathrm{Ca})$ and magnesium $(\mathrm{Mg})$ respectively, described in Magro (2012).

The study was carried out between March 2011 and February 2012, in an experiment in progress, where there was Pinus (Pinus taeda) cultivated for two cycles. The first cycle was started in 1962 year and finished in 1987 year with mechanized harvesting and the second was started in 1987 and finished in 2009 also with mechanized harvesting. The harvest was done by use of Feller Buncher with belt model Tigercat L879C, and the trees were dragged by wheel skidder (traction 6 x 6) model Tigercat 636C. After delimbing, the treetops were cut off by harvester model 909L with a Waratah $622 \mathrm{~B}$ head and the residues were chopped and removed from the area, almost completely, remaining the soil partially covered at the time of the eucalyptus plantation (Eucalyptus benthamii) (Magro, 2012), in January, 2010.

Revista Árvore. 2017;41(6):e410606 
The treatments consisted of three forms of soil preparation, two with mechanical subsoiling and one manual, in three replications distributed in three blocks: i) subsoiling in downslope direction (SD); ii) subsoiling in contour on the slope (SC); iii) manual holes (MH). In SD and in SC the grooves were spaced $2.5 \mathrm{~m}$ apart and the eucalyptus seedlings $2.5 \mathrm{~m}$ apart from each other in the line (45 plants per plot). In the SD five grooves were formed per plot and in the SC nine grooves. In the $\mathrm{MH}$, the pit holes were spaced $2.5 \mathrm{~m}$ apart (45 pit holes also with 45 plants per plot). The subsoiling was performed with a 70HP track-type tractor, where the stems operated at a depth of $0.45 \mathrm{~m}$, breaking 0.3 $\mathrm{m}$ of soil to each side of the stem. The pit holes in the PCM had dimensions of $0.3 \times 0.3 \times 0.3 \mathrm{~m}$.

The plot was installed with dimensions of $12 \times 24$ $\mathrm{m}\left(288 \mathrm{~m}^{2}\right)$, being the slope-wise length the greatest, which was delimited in the contour by means of galvanized sheets of $0.4 \mathrm{~m}$ of height, buried $0.2 \mathrm{~m}$ into the ground. At the lower base, $0.6 \mathrm{~m}$ high sheets buried $0.4 \mathrm{~m}$ into the ground directed the runoff from the plot to the two collecting tanks located at the lower end of the slope. The two tanks had a capacity of 400 and $500 \mathrm{~L}$, respectively in the first and in the second. The first one had 13 "Geibb" partition windows on the top edge of the tank and thus directed $1 / 13$ of the runoff to the second tank. In the first tank, was stored the runoff containing larger diameter and/or denser sediments and, in the second, the runoff containing the smaller diameter and/or less dense sediments.

The quantification of the runoff was done by means of weekly collection of the volume present in the collecting tanks, whenever erosive rains occurred, each with $10 \mathrm{~mm}$ or more, as conceptualized by Wischmeier and Smith (1978). The height of the runoff blade, stored in each tank, was measured with the aid of a graduated ruler and, from that height, the runoff volume was obtained. In the case of the second tank, the runoff volume measured was multiplied by 13 , due to the existence of the "Geibb" divider with 13 windows. The monthly and annual losses by runoff were obtained by the sum of the weekly runoff.

The runoff samples (water plus sediments) were collected whenever rainfall occurred, accumulated monthly, or in different time periods depending on the occurrence of rains, from March 2011 to February 2012, totaling 39 collections during the year. Two samples were collected per tank for quantification of water and soil losses in glass bottles with a capacity of $300 \mathrm{~cm}^{3}$.
During collection, the runoff was stirred in the tank to homogenize the water and the sediments to collect representative samples of the suspension. In the laboratory, the samples were weighed, sediment settling was awaited after addition of hydrochloric acid $\left(50 \mathrm{~g} \mathrm{~L}^{-1}\right)$ and the supernatant water was removed. Right after that, they were taken to the greenhouse where they were dried at $50^{\circ} \mathrm{C}$. Afterwards, they were weighed and, with this, the water and soil losses were calculated following the methodology described in Cogo (1978). The rainfall height was quantified considering the average value recorded in three rain gauges (Pluviometers) distributed within the experimental area.

Due to the slope variation between the plots, the soil loss data observed were adjusted to the mean slope by the procedure recommended by Wischmeier and Smith (1978). The effect of the treatments was analyzed using the residual variance, with the application of the Tukey test $(p \leq 0.05)$ for the comparison of means whenever there was a difference between them, considering three blocks in which the treatments were distributed completely randomly in each block, through the ASSISTAT software.

\section{RESULTS}

The annual rainfall height observed during the research period $(1,736 \mathrm{~mm})$ was $8.5 \%$ higher than the average historical height of the region that, according to Magro (2012), is $1,600 \mathrm{~mm}$, and the difference was most prominent in the months of March, July and August 2011 (Table 1). During the other months of 2011, the rainfall height of the historic series was higher than observed, highlighting October to December 2011 and February 2012 as the most significant, while in the other months, the historical and the observed values were similar.

Water losses (WL) did not differ statistically between treatments, while soil losses (SL) varied ( $p$ $<0.05$ ); temporally, only numerical variation occurred in some months (Table 2 ). Water losses and SL increased with increasing rainfall height, whose data fit a linear model significantly (Figure 1). Water losses were explained in $77 \%$ by rainfall height (Figure 1a), while SL were explained in 74\% (Figure 1b).

Considering the relationship between SL and WL, the coefficient values were 0.93 and 0.88 respectively for the monthly losses (Figure 2a) and for the data 
of each collection in the sum of the three treatments (Figure 2b). In Figure 2a, SL were explained by WL, with significant adjustment in both cases $(p \leq 0.01)$, proving that the points dispersion was low, characterizing a relatively strong relation between the variables. This occurred even considering the fact that the soil cover by vegetal residue had dissipated the rain energy. In cases like this, SL can be explained only by the surface runoff.

\section{DISCUSSION}

Water and soil losses were temporally influenced by the monthly variation of height of the observed rains (Table 1). It should be noted that rainfall height is more important than its mean intensity on soil erosion in forest condition where the soil is permanently covered by crop residues, in the case of natural rainfall (Bertol et al., 2010). In this case, the impact of the raindrops has less influence than the surface runoff on the erosion, unlike what happens in uncovered soil where the impact of droplets is more important (Wischmeier and Smith, 1978; Zhou etal., 2002). The monthly values of rainfall (Table 1) ranged from month to month, sometimes being higher, sometimes lower, according to the normal climatic variation of the region. With this, water and soil losses varied monthly, influenced by the excess of rainwater that became a runoff, among other factors.

The WL by runoff did not vary spatially $(p<0.05)$ between treatments, showing only a numerical distinction between them (Table 1). This is normal because
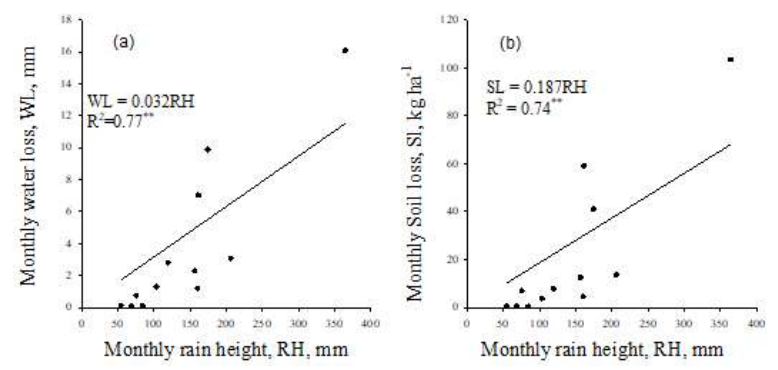

Figure1- Relationship (a) of water losses with rain height, and (b) soil loss with rain height, considering the monthly values from 2011 to 2012 (average of repetitions of the three treatments), in a Humic Dystrudept.

Figura 1-Relação (a) das perdas de água com a altura da chuva, e (b) perda de solo com a altura da chuva, considerando os valores mensais de 2011 a 2012 (média das repetições dos três tratamentos), em um Cambissolo Háplico. the soil has a water infiltration limit (Volk and Cogo, 2014) that controls the surface runoff. In addition, the coefficient of variation (CV) values were high, explained by the differences observed between the repetitions, with the lowest coefficient of variation values between May and August, and the highest CV values, in November and December. Thus, the residual effect resulting from the soil tillage variation carried out during the pine planting three years previously was not enough to cause these treatments to express differences in WL in the form of runoff in the present study. The spatial numerical distinction of WL was due in large part to the influence of the type of soil preparation and, in part, to the normal variability of the surface characteristics of the soil, covering and roughness, partially controlled experimentally.

Coverage and roughness are the main soil surface characteristics that influence start time, rate of increase and total volume of surface runoff (Schwab et al., 1993; Volk and Cogo, 2014). The largest spatial numerical differences in WL between treatment repetitions and between treatments were observed in November, December, and February, while in May, July and September the lowest differences occurred (Table 2). It is possible to infer that the probable lower water content in the soil in the months of higher temperature resulted in higher runoff variability at this time of year due to the higher evaporative demand (Wrege et al., 2011). In the lower temperature months there
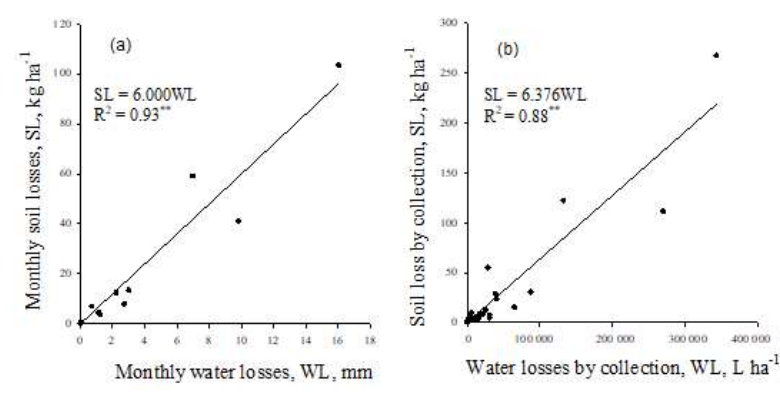

Figure 2 - Relationship between (a) the average monthly values of soil losses and water loss and (b) the sum of the total values of the three treatments per collection, for the period 2011-2012, in a Humic Dystrudept.

Figura 2-Relação entre (a) os valores médios mensais de perdas de solo e perda de água e (b) a soma dos valores totais dos três tratamentos por coleta, para o período 2011-2012, em um Cambissolo Háplico.

Revista Árvore. 2017;41(6):e410606 
Table 1 - Monthly and total annual rainfall values observed in the period of the survey, historical average rainfall of the research site and water losses by runoff, in the repetitions and average of treatments, in the period from 2011 to 2012, in a Humic Dystrudept.

Tabela 1 - Valores pluviométricos mensal e total anual observados no período da pesquisa, precipitação pluviométrica média do local da pesquisa e perdas de água por escoamento superficial, nas repetições e na média dos tratamentos, no período de 2011 a 2012, em um Cambissolo Háplico.

\begin{tabular}{|c|c|c|c|c|c|c|c|c|c|c|c|c|c|c|c|}
\hline \multirow[t]{2}{*}{ Month } & \multirow[t]{2}{*}{ Rain } & \multirow{2}{*}{$\begin{array}{c}\text { Historical } \\
\text { Average }\end{array}$} & \multicolumn{12}{|c|}{ Water loss, by replicate and in average for each treatment } & \multirow[t]{2}{*}{$\mathrm{CV}$} \\
\hline & & & $\overline{\mathrm{SD}}$ & SD & SD & Ave & $\mathrm{SC}$ & $\mathrm{SC}$ & $\mathrm{SC}$ & Ave & MH & $\mathrm{MH}$ & MH & Ave & \\
\hline & & & & & & & & $\mathrm{mn}$ & & & & & & & $\%$ \\
\hline Mar & 162 & 112 & 20.4 & 19.5 & 3.3 & 14.4 & 2.9 & 4.5 & 3.5 & 3.6 & 2.1 & 4.2 & 2.5 & 2.9 & 80 \\
\hline Apr & 76 & 117 & 0.9 & 0.4 & 0.4 & 0.6 & 0.5 & 1.0 & 1.6 & 1.0 & 0.3 & 0.5 & 0.9 & 0.6 & 56 \\
\hline Mai & 157 & 129 & 2.4 & 1.7 & 2.2 & 2.1 & 1.9 & 2.7 & 2.9 & 2.5 & 1.5 & 2.3 & 2.7 & 2.2 & 23 \\
\hline Jun & 104 & 107 & 1.9 & 0.8 & 1.0 & 1.2 & 1.1 & 1.8 & 2.1 & 1.7 & 0.6 & 0.8 & 1.2 & 0.9 & 38 \\
\hline Jul & 207 & 117 & 4.1 & 2.4 & 2.6 & 3.0 & 2.5 & 3.7 & 3.7 & 3.3 & 1.6 & 3.3 & 3.5 & 2.8 & 30 \\
\hline Aug & 365 & 80 & 23.3 & 16.5 & 14.6 & 18.1 & 11.7 & 16.6 & 11.5 & 13.3 & 6.5 & 29.5 & 14.0 & 16.7 & 47 \\
\hline Sep & 175 & 167 & 13.3 & 18.3 & 6.9 & 12.8 & 4.9 & 20.0 & 5.2 & 10.0 & 2.9 & 14.3 & 2.6 & 6.6 & 72 \\
\hline Oct & 120 & 181 & 4.4 & 3.5 & 2.5 & 3.5 & 1.9 & 3.8 & 2.9 & 2.9 & 0.7 & 3.6 & 1.6 & 2.0 & 42 \\
\hline Nov & 85 & 127 & 0.2 & 0.1 & 0.0 & 0.1 & 0.0 & 0.1 & 0.3 & 0.1 & 0.0 & 0.1 & 0.0 & 0.0 & 124 \\
\hline Dec & 55 & 154 & 0.1 & 0.2 & 0.1 & 0.1 & 0.0 & 0.1 & 0.3 & 0.1 & 0.0 & 0.0 & 0.0 & 0.0 & 106 \\
\hline Jan & 161 & 167 & 1.0 & 2.9 & 0.2 & 1.4 & 0.7 & 1.4 & 1.8 & 1.3 & 0.1 & 2.1 & 0.2 & 0.8 & 94 \\
\hline Feb & 69 & 142 & 0.0 & 0.1 & 0.0 & 0.0 & 0.0 & 0.1 & 0.1 & 0.1 & 0.0 & 0.0 & 0.0 & 0.0 & 141 \\
\hline Total1. & 736 & 1.600 & 72.0 & 66.4 & 33.8 & 57.3 & 28.1 & 55.8 & 35.9 & 39.9 & 16.3 & 60.7 & 29.2 & 35.5 & 36 \\
\hline
\end{tabular}

SD: subsoiling in downslope direction; SC: subsoiling in contour on the slope; $\mathrm{MH}$ : manual holes (MH). Ave: average. CV = coefficient of variation.

was lower variability of runoff values, due to the higher water content in the soil due to the lower evaporative demand.

The temporal numerical variation of the surface runoff generally followed the observed rainfall variation (Table 1), so that the highest runoff values occurred in March, July, August, and September, and the lowest in November, December, January, and February. This temporal numerical variation of the WL was normal, due in great part to the variation of water content in the soil between the months, due to the variation of the rain height influenced by the climatic variation of the region. The water content of the soil predating rainfall and the rainfall height are hydrological variables that strongly influence WL through surface runoff

Table 2 - Monthly and annual values of rainfall and total soil loss by water erosion, in replicates and treatments average, in 2011 and 2012, in a Humic Dystrudept.

Tabela 2 - Valores mensal e total anual de chuva e de perdas de solo por erosão hídrica, nos tratamentos, por repetição, no período de 2011 a 2012, em um Cambissolo Háplico.

\begin{tabular}{|c|c|c|c|c|c|c|c|c|c|c|c|c|c|c|}
\hline \multirow[t]{2}{*}{ Month } & \multirow[t]{2}{*}{ Rain } & \multicolumn{12}{|c|}{ Soil loss, by replicate and in average for each treatment } & \multirow[t]{2}{*}{$\mathrm{CV}$} \\
\hline & & SD & SD & SD & Ave & $\mathrm{SC}$ & $\mathrm{SC}$ & $\mathrm{SC}$ & Ave & $\mathrm{MH}$ & MH & MH & Ave & \\
\hline & & & & & & $\mathrm{K}$ & $\mathrm{ha}^{-1}$ & & & & & & & $\overline{\%}$ \\
\hline Mar & 162 & 160.0 & 152.9 & 20.6 & 111.2 & 61.9 & 76.7 & 26.5 & 55.0 & 4.0 & 23.8 & 3.6 & 10.5 & 65 \\
\hline Apr & 76 & 15.5 & 12.7 & 5.6 & 11.3 & 4.4 & 11.6 & 5.7 & 7.2 & 0.5 & 3.7 & 1.1 & 1.8 & 51 \\
\hline Mai & 157 & 38.8 & 21.9 & 20.0 & $26.9 a$ & 2.0 & 10.5 & 6.6 & $6.4 \mathrm{ab}$ & 1.3 & 8.2 & 1.2 & $3.6 b$ & 63 \\
\hline Jun & 104 & 2.0 & 8.0 & 7.9 & 6.0 & 0.6 & 8.7 & 1.5 & 3.6 & 0.3 & 2.2 & 0.5 & 1.0 & 67 \\
\hline Jul & 207 & 22.0 & 35.5 & 19.7 & $25.7 \mathrm{a}$ & 6.9 & 14.8 & 6.0 & $9.2 b$ & 2.0 & 8.8 & 3.8 & $4.9 b$ & 21 \\
\hline Aug & 365 & 160.0 & 241.4 & 119.9 & $173.8 \mathrm{a}$ & 86.9 & 171.5 & 48.1 & $102.2 \mathrm{~b}$ & 14.0 & 65.1 & 21.5 & $33.5 \mathrm{c}$ & 22 \\
\hline Sep & 175 & 76.0 & 130.1 & 26.1 & $77.4 \mathrm{a}$ & 25.8 & 66.6 & 12.5 & $35.0 \mathrm{ab}$ & 9.9 & 18.0 & 2.3 & $10.1 \mathrm{~b}$ & 55 \\
\hline Oct & 120 & 12.5 & 20.6 & 12.5 & $15.2 \mathrm{a}$ & 1.9 & 15.3 & 1.8 & $6.3 \mathrm{ab}$ & 0.3 & 2.9 & 1.0 & 1.4 & 42 \\
\hline Nov & 85 & 0.3 & 0.2 & 0.2 & $0.2 \mathrm{a}$ & 0.1 & 0.2 & 0.2 & $0.2 \mathrm{a}$ & 0.0 & 0.1 & 0.0 & $0.0 \mathrm{~b}$ & 46 \\
\hline Dec & 55 & 0.2 & 1.5 & 0.3 & 0.7 & 0.0 & 0.4 & 0.4 & 0.3 & 0.0 & 0.3 & 0.0 & 0.1 & 102 \\
\hline Jan & 161 & 2.1 & 20.0 & 1.2 & 7.8 & 1.5 & 8.8 & 2.5 & 4.3 & 0.1 & 2.5 & 0.3 & 1.0 & 111 \\
\hline Feb & 69 & 0.0 & 0.7 & 0.0 & 0.2 & 0.0 & 0.7 & 0.1 & 0.3 & 0.0 & 0.1 & 0.0 & 0.0 & 109 \\
\hline Total & 1.736 & 489.4 & 645.5 & 234.0 & $456.4 \mathrm{a}$ & 192.0 & 385.8 & 111.9 & $230.0 \mathrm{ab}$ & 32.4 & 135.7 & 35.3 & $67.9 \mathrm{~b}$ & 34 \\
\hline
\end{tabular}

SD: subsoiling in down slope direction; SC: subsoiling in contour on the slope; MH: manual holes (MH). Ave: average. CV = coefficient of variation. 
Table 3 - Rain height, water loss and soil losses for the season in the 2011-2012 period, the three treatments in a Humic Dystrudept.

Tabela 3 - Altura da chuva, perdas de água e perdas de solo por estação, no período 2011-2012, nos três tratamentos em um Cambissolo Háplico.

\begin{tabular}{|c|c|c|c|}
\hline \multirow[t]{2}{*}{$\begin{array}{l}\text { Weather } \\
\text { Station }\end{array}$} & Rain & WL & SL \\
\hline & $\mathrm{mm}$ & $\mathrm{m}^{3} \mathrm{ha}^{-1}$ & $\mathrm{~kg} \mathrm{ha}^{-1}$ \\
\hline & & & \\
\hline Autumn & 395 & $123 \mathrm{~b}$ & 131 \\
\hline Winter & 676 & $225 \mathrm{a}$ & $213 a$ \\
\hline Spring & 381 & $165 \mathrm{~b}$ & $98 \mathrm{~b}$ \\
\hline Summer & 284 & $15 \mathrm{c}$ & $14 \mathrm{c}$ \\
\hline Total & 1.736 & 528 & 456 \\
\hline \multirow[t]{2}{*}{$\mathrm{CV}(\%)$} & - & 25 & 29 \\
\hline & & & \\
\hline Autumn & 395 & $72 \mathrm{~b}$ & $64 \mathrm{~b}$ \\
\hline Winter & 676 & $182 \mathrm{a}$ & $115 \mathrm{a}$ \\
\hline Spring & 381 & $130 \mathrm{a}$ & $44 \mathrm{~b}$ \\
\hline Summer & 284 & $15 \mathrm{c}$ & $7 \mathrm{c}$ \\
\hline Total & 1.736 & 399 & 230 \\
\hline \multirow[t]{2}{*}{$\mathrm{CV}(\%)$} & - & 36 & 32 \\
\hline & & & \\
\hline Autumn & 395 & $57 \mathrm{~b}$ & $10 \mathrm{~b}$ \\
\hline Winter & 676 & $203 \mathrm{a}$ & $25 \mathrm{a}$ \\
\hline Spring & 381 & $86 \mathrm{~b}$ & $32 \mathrm{a}$ \\
\hline Summer & 284 & $8 \mathrm{c}$ & $1 \mathrm{c}$ \\
\hline Total & 1.736 & 354 & 68 \\
\hline $\mathrm{CV}(\%)$ & - & 39 & 42 \\
\hline
\end{tabular}

(Wischmeier and Smith, 1978). It is noteworthy that WL were low in this research, regardless of the treatment, varying between $2.0 \%$ and $3.3 \%$ of the yearly total precipitation. It is differ from what happened in the research carried out in the first year of this experiment, which was conducted by Magro (2012). A more significant difference in WL verified by Magro (2012) occurred in the SD treatment in which the values were equivalent to $14 \%$ of the rain, while in this research they were only $3.3 \%$ of the rainfall. The open grooves allowed the free flow of water down the slope in the first research, while in this research the grooves were practically closed by the litter. Plant residues exert a physical barrier against runoff, according to Amaral et al. (2008) and the growth of tree roots increase the internal galleries in the soil. On the whole, this should have contributed to the low WL in the present research, as these are factors that increase water infiltration in the soil, according to Chirino et al. (2006) and Oliveira (2012).

Revista Árvore. 2017;41(6):e410606
The WL by runoff in this research (Table 1) were lower than WL verified by Magro (2012) in the first year of cultivation. The low amount of water lost in this research was due to the increase in the canopy of plants from the second year of eucalyptus development, which may have promoted greater interception of rainwater through the canopy. The increased litter and the tree growth in forest areas increase the interception of rainwater in the canopy and the water retention at soil level, increasing the infiltration of water into the soil (Lima, 1988; Wichert, 2005; Oliveira, 2012). The residual effect of land use and soil management usually occurs over a period of time that is not very long due mainly to the effect of rainfall and surface runoff on the soil, in the case of natural rainfall (Amaral et al., 2008) as well as in simulated rains (Luciano et al., 2009; Panachuki et al., 2011).

The numerical variation of SL from one month to the other (Table 2) generally followed the rain height variation. This variation was normal, mainly due to the variation of water content in the soil between the moments of rainfall and, in part, to the variation in of the rain height from one month to the other. The soil water content before rainfall and the rainfall height are variables that strongly influence the surface runoff(Wischmeier and SMITH, 1978) which, in this case, was the main agent causing erosion, since the soil was practically covered by the litter. In areas where the soil is covered by the vegetal residues, water erosion is mainly explained by surface runoff water (Panachuki et al., 2011; Schick et al., 2017).

The variation of SL between treatments occurred in May, July, August, September, October, and November (Table 2), and was due to the residual effect of the type of soil tillage that had been carried out at the time of experiment installation. In addition, it can be inferred that the lower water content in the soil in the months of higher temperature caused greater variability in erosion and, in the months of lower temperature when the water content in the soil was higher, there was less variability in the SL data. Coverage and roughness are the main surface characteristics that influence soil water infiltration and, therefore, surface runoff and soil erosion, as reported by Schwab et al. (1993) and Ramos et al. (2014).

Soil losses due to water erosion were higher in the SD treatment compared to the others, in May, July, August, September, and October, and in November, the losses in this treatment exceeded only the ones of the SC 
(Table 2). These results are in agreement with those of Wichert (2005) and Baptista and Levien (2010), according to which subsoiling in the declivity direction increases erosion compared to the manual opening of grooves on the ground. The losses verified annually, although high from the point of view of the environmental preservation outside the place of origin of erosion, were low as to the maintenance of the studied soil productive capacity, compared to the tolerance of this type of soil, which is around $9 \mathrm{Mg} \mathrm{ha}^{-1}$ year $^{-1}$ (Bertol and Almeida, 2000).

Soil loss values determined in this study were low compared to those observed by Magro (2012), which were of the order of $19.7 \mathrm{Mg} \mathrm{ha}^{-1}$ year $^{-1}$ in the SD treatment and 2.2 and $0.9 \mathrm{Mg} \mathrm{ha}^{-1}$ year $^{-1}$, respectively in the treatments $\mathrm{SC}$ and $\mathrm{MH}$. At that time, the soil was uncovered, newly made for planting in the slope direction, still open. The highest values of SL in the treatment in which the subsoiling operation was carried out in the slope direction(SD), especially in the months in which the statistical analysis showed difference between the treatments $(p<0.05)$, mean that this form of soil management is not recommended for the planting of forest species. The SL in the treatment in which the planting was done down the slope were twice as high as when the subsoiling was carried out on-contour and were 6.7 times higher than in the case of individual grooves manually opened, considering the yearly total. These results disagree with those obtained by Brito et al. (2005), who, evaluating the SL in Red Oxisol in eucalyptus cultivation, realized that planting orientation did not influence water erosion.

The increasing linear relationship between the values of soil and water loss and the rainfall height values (Figure 1) means that the rate of soil and water loss increased progressively with increasing rainfall height. Relations similar to this were observed by observed by Baptista and Levien (2010), in a study of water erosion in a Eucalyptus saligna forest in a Haplic Cambisol.

The linear increase of WL and SL with increasing rainfall height, as seen in figure 1 was expected, therefore can be considered as normal, since the slope of the terrain within the plots was uniform, corroborating the results obtained by Gobbi et al. (2011). The similarity between these relationships and those found in the aforementioned literature was not expected, in part because they were obtained in forest condition, while those of other authors were found under agricultural conditions. As to the case of the relationship between
SL and rain height (Figure 1b), the increasing linearity was also not expected, since SL increase linearly with increasing rainfall energy (Wischmeier and Smith, 1978; Schick et al., 2017). This type of relationship was also not expected here either, since this study was carried out in forest condition and the studies by Wischmeier and Smith (1978) and Schick et al. (2017) were done under uncovered soil condition and with agricultural cultivation.

The value of $\mathrm{R}^{2}$ slightly lower in the relation of SL (Figure 1b) than in that of WL (Figure 1a), both with rainfall height, is explain by the fact that some SL values were relatively high at relatively low rainfall values and vice versa. This is expected from data obtained in erosion experiments of this nature, in which the variability of the factors influencing water erosion is high, especially the water content in the soil preceding the rains, which is absolutely not controllable experimentally (Brito et al., 2005; Amaral et al., 2008; Baptista and Levien, 2010).

The highest values of water and soil losses occurred in winter, which was also the climatic season with the greatest rainfall height, regardless of the treatment (Table 3). As for the case of SL, it was possibly due to the erosivity of these rains related to their volume during that period. Although erosivity had not been calculated by the standard method recommended by Wischmeier and Smith (1978), it is possible to estimate that it was higher in that season due to the greater volume of rainfall at that time of year. This statement is based on the work carried out by Schick et al. (2014) considering the rains of Lages city in Santa Catarina State. The higher WL in this season can be attributed to the higher water content in the soil due to the lower evaporative demand (lower temperature) and the higher precipitation volume, which accelerated the onset of surface runoff, increasing the runoff volume. Both water and soil losses tended to be higher in the season with the greatest volume of rain, being higher in winter and lower in summer, regardless of the treatment.

\section{CONCLUSIONS}

The planting of Eucalyptus benthamii on grooves opened by subsoiler in the slope direction weakens the soil as to the water erosion in comparison to the plantations made in grooves on-contour of the slope and in pit holes; the difference is $25 \%$ for water losses and $53 \%$ for soil losses.

Revista Árvore. 2017;41(6):e410606 
The plants of Eucalyptus benthamii provide a significant increase in soil resistance to runoff, evidencing that reforestation play an important role in the control of water erosion, regardless of the type of soil preparation adopted at the planting.

Soil losses due to water erosion are influenced in greater magnitude than water losses, regardless of the type of soil preparation used for the planting of Eucalyptus benthamii.

The water and soil losses are related to each other and to the rainfall height in positive linear relationship, regardless of the type of soil preparation used for planting Eucalyptus benthamii.

\section{REFERÊNCIAS}

Amaral A, Bertol I, Cogo NP, Barbosa FT. Redução da erosão hídrica em três sistemas de manejo do solo em um Cambissolo Húmico da região do Planalto Sul-Catarinense. Rev Bras Ciênc Solo. 2008;32(5):2145-55. http://dx.doi.org/ 10.1590/S0100-06832008000500035.

Baptista J, Levien R. Métodos de preparo de solo e sua influência na erosão hídrica e no acúmulo de biomassa da parte aérea de Eucaliptus saligna em um cambissolo háplico da depressão central do Rio Grande do Sul. Rev Arvore. 2010;34(4):567-75. http:// dx.doi.org/10.1590/S0100-67622010000400001.

Bertol I, Almeida JA. Tolerância de perda de solo por erosão para os principais solos do Estado de Santa Catarina. Rev Bras Ciênc Solo. 2000;24(3):657-68. http://dx.doi.org/10.1590/S0100-06832000000300018.

Bertol I, Vázquez EV, González AP, Cogo NP, Luciano RV, Fabian EL. Sedimentos transportados pela enxurrada em eventos de erosão hídrica em um Nitossolo Háplico. Rev Bras Ciênc Solo. 2010;34(1):245-52. http:// dx.doi.org/10.1590/S0100-06832010000100025.

Brito LF, Silva MLN, Curi N, Leite FP, Ferreira MM, Pires LS. Erosão hídrica de Latossolo Vermelho muito argiloso relevo ondulado áreas de pós-plantio de eucalipto no Vale do Rio Doce região Centro Leste do estado de Minas Gerais. Sci For. 2005;67:27-36.

Chirino E, Bonet A, Bellot J, Sanchez JR. Effects of 30-year-old Aleppo pine plantations on runoff, soil erosion, and plant diversity in a semi-arid landscape in south eastern Spain. Catena. 2006;65(1):19-29. http://dx.doi.org/10.1016/ j.catena.2005.09.003.

Cogo NP. Uma contribuição à metodologia de estudo das perdas por erosão em condições de chuva natural: I - Sugestões gerais, medição de volume, amostragem e quantificação de solo e água da enxurrada. In: Anais do Encontro Nacional de Pesquisa sobre Conservação do Solo; 1978; Passo Fundo. Passo Fundo: Empresa Brasileira de Pesquisa Agropecuária; 1978. p. 7597.

Gobbi E, Bertol I, Barbosa FT, Werner RS, Ramos RR, Paz-Ferreiro J, et al. Erosão hídrica associada a algumas variáveis hidrológicas em pomar de maçã submetido a diferentes manejos do solo. Rev Bras Ciênc Solo. 2011;35(3):1013-24. http:// dx.doi.org/10.1590/S0100-06832011000300035.

Gonçalves JLM, Stape JL. Conservação e cultivo de solos para plantações florestais. Piracicaba: Instituto de Pesquisas e Estudos Florestais; 2002. $498 \mathrm{p}$.

Hudson NW. Soil conservation. 3rd ed. Ithaca: Cornell University Press; 1995. 324 p.

Lima WP. Escoamento superficial, perdas de solo e de nutrientes em microparcelas reflorestadas com eucalipto em solos arenosos no município de São Simão, SP. Piracicaba: Instituto de Pesquisas e Estudos Florestais; 1988. p. 5-16.

Luciano RV, Bertol I, Barbosa FT, Vázquez EV, Fabian EL. Perdas de água e solo por erosão hídrica em duas direções de semeadura de aveia e ervilhaca. Rev Bras Ciênc Solo. 2009;33(3):669-76. http://dx.doi.org/10.1590/S0100-06832009000300019.

Magro BA. Perda de solo, água e nutrientes em três sistemas de preparo de solo florestal [dissertação]. Curitiba, PR: Universidade Federal do Paraná; 2012.

Martins SG, Silva MLN, Curi N, Ferreira MM, Fonseca S, Marques JJGSM. Perdas de solo e água por erosão hídrica em sistemas florestais na região de Aracruz (ES). R. Bras. Ci. Solo. 2003;27(3):395-403. http://dx.doi.org/10.1590/S010006832003000300001. 
Oliveira AH, Silva MLN, Curi N, Avanzi JC, Klinke GN No, Araújo EF. Water erosion in soils under eucalyptus forest as affected by development stages and management. Cienc Agrotec. 2013;37(2):159-69. http://dx.doi.org/10.1590/S141370542013000200007.

Oliveira LC. Erosão hídrica e alguns processos hidrológicos em plantios de Pinus, mata e campo nativos e estrada florestal [tese]. Lages, SC: Universidade do Estado de Santa Catarina; 2012.

Panachuki E, Bertol I, Alves Sobrinho T, Oliveira PTS, Rodrigues DBB. Perdas de solo e água e infiltração de água em Latossolo Vermelho sob sistemas de manejo. Rev Bras Ciênc Solo. 2011;35(5):1777-86. http://dx.doi.org/10.1590/S010006832011000500032 .

Pires LS, Silva MLN, Curi N, Leite FP, Brito LF. Erosão hídrica pós-plantio em florestas de eucalipto na região centro-leste de Minas Gerais. Pesqui Agropecu Bras. 2006;41(4):687-95. http:// dx.doi.org/10.1590/S0100-204X2006000400021.

Ramos JC, Bertol I, Barbosa FT, Marioti J, Werner RS. Influência das condições de superfície e do cultivo do solo na erosão hídrica em um cambissolo húmico. Rev Bras Ciênc Solo. 2014;38(5):1587-600. http://dx.doi.org/10.1590/S010006832014000500024 .

Schick J, Bertol I, Barbosa FT, Miquelluti DJ, Cogo NP. Water erosion in a long-term experiment with different soil management systems. Rev Bras Ciênc Solo. 2017;41:e0160383. http://dx.doi.org/10.1590/ 18069657 rbcs 20160383 .

Schick J, Bertol I, Cogo NP, Paz González A. Erosivity of rainfall in Lages, Santa Catarina, Brazil. Rev Bras Ciênc Solo. 2014;38(6):1890-905. http:// dx.doi.org/10.1590/S0100-06832014000600024.
Schwab GO, Fangmeier DD, Elliot WJ, Frevert RK. Soil and water conservation engineering. 4th ed. New York: John Wiley \& Sons; 1993. $507 \mathrm{p}$.

Soil Survey Staff. Keys to soil taxonomy. 12th ed. Washington: United States Department of agriculture, Natural Resources Conservation Service; 2014.

Volk LBS, Cogo NP. Erosão hídrica, em três momentos da cultura do milho, influenciada por métodos de preparo do solo e semeadura. Rev Bras Ciênc Solo. 2014;38(2):565-74. http:// dx.doi.org/10.1590/S0100-06832014000200021.

Wichert MCP. Erosão hídrica e desenvolvimento inicial do Eucalyptus grandis em um Argissolo Vermelho amarelo submetido a diferentes métodos de preparo de solo no Vale do ParaíbaSP [dissertação]. Piracicaba, SP: Universidade de São Paulo, Escola Superior de Agricultura "Luiz de Queiros"; 2005.

Wischmeier WH, Smith DD. Predicting rainfall erosion losses: a guide to conservation planning. Washington: USDA; 1978.58 p. (Agricultural Handbook; 537).

Wrege MS, Steinmetz S, Reisser C Jr, Almeida IR, editors. Atlas climático da Região Sul do Brasil: Estados do Paraná, Santa Catarina e Rio Grande do Sul. Pelotas: Embrapa Clima Temperado; Colombo: Embrapa Florestas; 2011.

Zhou GY, Morris JD, Yan JH, Yu ZY, Peng SL. Hydrological impacts of refforestation with eucalypts and indigenous species: a case study in Southern China. For Ecol Manage. 2002;167(1-3):209-22. http://dx.doi.org/10.1016/ S0378-1127(01)00694-6. 